\title{
Evaluation of the ameliorative roles of Vitamins A, C and E on reduced glutathione in Clarias gariepinus (Burchell, 1822) fingerlings exposed to cadmium chloride
}

\author{
Patrick Ozovehe Samuel 1, *, Francis Ofurum Arimoro ${ }^{1}$, Adesola Victoria Ayanwale ${ }^{1}$ and Hadiza Lami \\ Mohammad 2 \\ ${ }^{1}$ Fisheries and Hydrobiology Unit, Department of Animal Biology, Federal University of Technology, Minna, Niger State. \\ ${ }^{2}$ Biochemistry Department, Federal University of Technology, Minna, Niger State.
}

GSC Biological and Pharmaceutical Sciences, 2021, 15(03), 052-062

Publication history: Received on 23 April 2021; revised on 29 May 2021; accepted on 31 May 2021

Article DOI: https://doi.org/10.30574/gscbps.2021.15.3.0144

\begin{abstract}
Effects of cadmium chloride on the production of antioxidants such as reduced glutathione (GSH) in Clarias gariepinus and how such effects can be ameliorated through administration of vitamins were investigated. C. gariepinus fingerlings were exposed to sub-lethal concentrations of $\mathrm{Cd}(00,12 \mathrm{mg} / \mathrm{L}, 16 \mathrm{mg} / \mathrm{L}, 20 \mathrm{mg} / \mathrm{L}$ and $24 \mathrm{mg} / \mathrm{L})$ with replicate in each case. $12 \mathrm{mg} / \mathrm{L}$ each of the vitamins were administered across all bud. Fresh concentrations of both toxicant and vitamins were administered every 72 hours for a period of 12 weeks every time the water medium was changed. 3 samples of the fish were randomly selected and sacrificed from each aquarium tank every 2 weeks. The gills, kidneys and liver were excised from these specimens, homogenized in sodium phosphate buffer and then assayed for GSH production levels in each case. From the results: In Cd only group, the highest GSH level produced in the liver was $38.85 \pm 0.07 \mu \mathrm{g} / \mathrm{ml}$. In the liver of samples of CdVA group, the value $(93.97 \pm 0.07 \mu \mathrm{g} / \mathrm{ml})$ increased then followed by the gill $(67.72 \pm 0.13 \mu \mathrm{g} / \mathrm{ml})$. In CdVC, the GSH production level in the gill $(39.76 \pm 0.07 \mu \mathrm{g} / \mathrm{ml})$ was relatively higher than livers and kidneys of the samples. In CdVE, the kidney produced the highest GSH value of $32.89 \pm 0.10 \mu \mathrm{g} / \mathrm{ml}$. The elicitation and utilization of the antioxidant at one point or the other were adopted by the fish in dealing with the effects of the toxicant especially in the presence of the vitamins. Higher concentrations of the vitamins could facilitate the understanding of the effects of the vitamins in mitigating the effects of the toxicant.
\end{abstract}

Keywords: Clarias gariepinus; GSH production level; Cd treatment groups; Ameliorative roles; Fish organs; Vitamins

\section{Introduction}

Fish is a rich source of animal protein throughout the world. Due to its nutritional value [29]; the demand for fish food has been on the increase with increasing human population $[13,14]$. African catfish, Clarias gariepinus is an important commercial fish due to its high growth rate, high consumer acceptability, and ability to withstand poor water quality, and oxygen depletion $[1,19]$. In Nigeria, Clarias species is an indigenous fish occurring in freshwater throughout the country. It is suspected that apart from tilapia, Clarias is the most abundant cultivated fish species in Nigeria [12]. The common species found are Clarias gariepinus, Clarias anguillaris, Clarias buthupogon and Clarias lazera.

Heavy metals induce significant damage to the physiological and biochemical processes of fish and subsequently to fish consumers [22]. Among all the heavy metals, Cd, arsenic, mercury and lead pose highest degree of toxicity and that is of great concern to both plants and human health [5]. Fish are particularly vulnerable and heavily exposed to pollutants due to feeding and living in aquatic ecosystems, because they cannot avoid pollutant harmful effects [3]. It is also known that, heavy metals enter fish by direct absorption from water through their gills and skin, or by ingestion of contaminated food [6].

\footnotetext{
* Corresponding author: Samuel Patrick Ozovehe

Fisheries and Hydrobiology Unit, Department of Animal Biology, Federal University of Technology, Minna, Niger State.
} 
Antioxidants that facilitate or confer protective capacity on organisms could be either enzymatic or non-enzymatic. Antioxidant enzymes are crucial in their effort to decrease oxidative stress produced by exposure to toxicants [26]. It has also been reported that antioxidants may ameliorate, protect and remove the oxidative damage to a target organ or molecule [10]. Non-enzymatic antioxidants such as vitamins $\mathrm{C}$ and $\mathrm{E}$ can also act to overcome oxidative stress, being a part of the total antioxidant system. They prevent the increased production of free radicals induced by oxidative damage to lipids and lipoproteins in various cellular compartments and tissues. For instance, increase in reduced glutathione (GSH) level in fish tissues was attributed to presence of defense system to protect the fish from the oxidative stress or could appear as an antioxidant adaptation to metal exposure [21]. Also, Hermenean et al. [17] observed that the liver has a higher capacity and adaptability to counteract ROS compared to kidney. Glutathione has been found in all mammalian cells, and has been demonstrated that GSH is responsible for protection against ROS and RNS, detoxification of endogenous and exogenous toxins of electrophilic nature [20]. Sharma and Ansari [27] also demonstrated that GSH level in both the tissues (brain and muscles) were decreased for all exposure periods. Sisein et al. [28] attributed the significantly lower GSH value in the liver of Clarias gariepinus from Gbarantoru swamp in comparison with Niger Delta University Agricultural farm (control) partly to the increased accumulation of heavy metals which led to more utilization of GSH to detoxify metals and ROS. In the same vein, Ayoola et al. [7] recorded significant differences in GSH, MDA, SOD and total protein in the gills of Hemichromis fasciatus and Chrysichthys nigrodigitatus collected from polluted Lagos lagoon.

The main biological function of vitamin $\mathrm{E}$ is its direct influence on cellular responses to oxidative stress through modulation of signal transduction pathway [24]. Vitamins E and C supplementation can induce protective effects on certain conditions after free radical-mediated cellular damage or disruption [30]. Vitamin E ( $\alpha$-tocopherol) is a fat soluble antioxidant that inhibits the production of reactive oxygen species formed when fat undergoes oxidation. A study has also shown how vitamin E and metallothionein treatments protected against Cd-induced damage of liver in grass carp by decreasing AST and ALT content, repairing organelles, and maintained the antioxidant system by elevating CAT, SOD, and GSH-Px activity and regulating related mRNA transcript expression [16]. This research therefore, attempted to determine the effects of Cd toxicant on the production of GSH in the exposed samples and how such effects can be ameliorated by the presence of vitamin supplements.

\section{Material and methods}

\subsection{Samples/materials collection and Acclimatization}

A total number of seven hundred and fifty (750) fingerlings of $C$. gariepinus were purchased from a commercial fish farmer and transported in 50L containers filled with water to the Old Farm Research Unit of the Department of Water, Aquaculture and Fisheries Technology, Bosso Campus, Federal University of Technology, Minna, Nigeria. The fishes were placed in fish ponds with water for acclimatization. The fishes were fed to satiation twice daily (morning and evening) with Blue Crown feed $(3 \mathrm{~mm}$ ) for 14 days ( 2 weeks). The holding water was changed every 3 days during the period.

The vitamins A, C and E granules or pellets (500g each) were purchased from commercial chemical stores. The toxicant, $\mathrm{Cd}(2$ units of $100 \mathrm{~g}$ ) analar grades were purchased from commercial chemical stores and stored in a cool dry condition throughout the period of the experiment. This toxicant was administered according to the sub-lethal concentrations of the treatments during the chronic phase of the exposure.

\subsection{Experimental Set-up}

Five treatments including control with two replicates in each treatment were set-up for the Cd, Vitamin A, C and E; and the sub-lethal exposures were run for a period of twelve (12) weeks. The treatments are 00 (control), 12mg/L, 16mg/L, $20 \mathrm{mg} / \mathrm{L}$ and $24 \mathrm{mg} / \mathrm{L}$, respectively. The groups of treatments were tagged Cd (Cd only with T1-T4 and replicates), second, CdVA (Cd+vitamin A with T1-T4 and replicates), third, CdVC (Cd+vitamin C with T1-T4 and replicates) and fourth, CdVE (Cd+vitamin E with T1-T4 and replicates). Each treatment was in two replicates containing 20 fish in $20 \mathrm{~L}$ plastic aquarium for the Cd, Vitamins A, C and E supplemented exposures. The water was changed and fresh toxicant and the vitamins with the same set of concentrations were added at every 72 hours according to Organization for Economic Co-operation and Development [23] standards. The minimum concentration of the toxicant served the same concentration for the uniform vitamin administration in each treatment. Three fish samples were picked at random and sacrificed from each trough on every $14^{\text {th }}$ day for the twelve weeks exposure period. The liver, gills and kidney were excised, homogenized in sodium phosphate buffer solution using ceramic mortar and pestle; and stored in sample tubes, then refrigerated until needed for analyses of GSH. 


\subsection{Preparation of sodium phosphate buffer}

Sodium phosphate buffer solution (0.2 M) was prepared from the mixture of sodium dihydrogen orthophosphate with $0.1 \mathrm{M}$ and disodium hydrogen orthophosphate with $0.1 \mathrm{M}$. The $\mathrm{pH}$ was adjusted to 8.0.

\subsection{Reduced Glutathione Bioassay}

The GSH (reduced glutathione) produced in each organ of the fish from each treatment and replicate were determined from their homogenates in in the Laboratory of Step B, Federal University of Technology, Bosso Campus, Minna, Niger State. The organs (gill, liver and Kidney) were homogenized using ceramic mortar and pestle with sodium phosphate

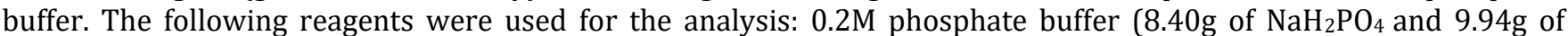
$\mathrm{Na}_{2} \mathrm{HPO}_{4}$ was dissolved in distilled water and made up to $1000 \mathrm{ml}$ mark in a volumetric flask. The buffer was adjusted to $\mathrm{pH} 8.0$ ); $10 \%$ Trichloroacetic acid (10g of TCA was dissolved in distilled water and made up to $100 \mathrm{ml}$ in the volumetric flask); and Ellman's reagent (19.8mg of 5,5'-Dithiobis Nitro Benzoic acid (DTNB) in 100ml of $0.1 \%$ sodium nitrate).

To $150 \mu \mathrm{L}$ of the tissue homogenate (in phosphate-saline pH 7.4), 1.5ml of $10 \%$ TCA was added, and centrifuge at $1500 \mathrm{~g}$ for $5 \mathrm{~min} .1 .0 \mathrm{ml}$ of the supernatant was treated with $0.5 \mathrm{ml}$ of Ellman's reagent and $3.0 \mathrm{ml}$ of phosphate buffer $(2.0 \mathrm{~m}$ pH 8.0). The absorbance was read at $412 \mathrm{~nm}$. Estimation of Reduced Glutathione was determined by the method of Ellman [9] as described by Rajagopalan et al. [25]. The amount of glutathione was calculated using a GSH standard curve and expressed as micron grams of GSH formed/mg protein in each case.

\subsection{Data Analysis}

The antioxidant levels in samples exposed to sub-lethal concentrations of the toxicants as well as those treatments supplemented with vitamins were analysed using One Way Analysis of Variance followed by Duncan Multiple Range Test to separate the means where significant at $\mathrm{P} \leq 0.05$ level of significance using SPSS Statistical Package (version 20.0 for Windows).

\section{Results}

GSH production levels in liver, kidneys and gills of $C$. gariepinus exposed to sub-lethal concentrations of $\mathrm{CdCl}_{2}$ toxicant and the respective supplemented treatments with Vitamins A, C and E for a period of twelve weeks and sampled fortnightly.

Table $1 \mathrm{GSH}$ production levels in the Liver of C. gariepinus exposed to sub-lethal concentrations of $\mathrm{CdCl}_{2}$ for a period of 12 weeks

\begin{tabular}{|l|l|l|l|l|l|l|}
\hline Treatment group & \multicolumn{1}{|c|}{$\mathbf{1}^{\text {st }}$} & \multicolumn{1}{|c|}{$\mathbf{2}^{\text {nd }}$} & $\mathbf{3}^{\text {rd }}$ & $\mathbf{4}^{\text {th }}$ & $\mathbf{5}^{\text {th }}$ & $\mathbf{6}^{\text {th }}$ \\
\hline CR & $19.76 \pm 0.13^{\mathrm{m}}$ & $7.26 \pm 0.13^{\mathrm{f}}$ & $13.51 \pm 0.07^{\mathrm{i}}$ & $19.03 \pm 0.10^{\mathrm{l}}$ & $9.42 \pm 0.07^{\mathrm{a}}$ & $57.83 \pm 0.13^{\mathrm{f}}$ \\
\hline T1 & $11.64 \pm 0.10^{\mathrm{h}}$ & $6.47 \pm 0.13^{\mathrm{d}}$ & $4.54 \pm 0.13^{\mathrm{a}}$ & $30.21 \pm 0.07^{\mathrm{m}}$ & $18.00 \pm 0.03^{\mathrm{f}}$ & $5.79 \pm 0.07^{\mathrm{a}}$ \\
\hline T2 & $9.37 \pm 0.10^{\mathrm{f}}$ & $15.45 \pm 0.13^{\mathrm{j}}$ & $10.56 \pm 0.72^{\mathrm{g}}$ & $7.37 \pm 0.13^{\mathrm{f}}$ & $0.00 \pm 0.00$ & $0.00 \pm 0.00$ \\
\hline T3 & $12.09 \pm 0.16^{\mathrm{i}}$ & $6.81 \pm 0.07^{\mathrm{de}}$ & $12.04 \pm 0.20^{\mathrm{i}}$ & $4.59 \pm 0.03^{\mathrm{c}}$ & $11.53 \pm 0.10^{\mathrm{b}}$ & $0.00 \pm 0.00$ \\
\hline T4 & $9.71 \pm 0.23^{\mathrm{fg}}$ & $6.92 \pm 0.07^{\mathrm{ef}}$ & $38.85 \pm 0.07^{\mathrm{l}}$ & $6.75 \pm 0.03^{\mathrm{e}}$ & $0.00 \pm 0.00$ & $0.00 \pm 0.00$ \\
\hline
\end{tabular}

Mean values and standard errors with different alphabets along the column are significantly different from each other at P $\leq 0.05$. Unit of GSH mean value is $\mu \mathrm{g} / \mathrm{ml}$.

In the liver of the samples of $C$. gariepinus exposed to sub-lethal concentrations of $\mathrm{CdCl}_{2}$, there were general low levels of production. The control mean values of GSH are significantly different from other treatments in the $2^{\text {nd }}$ week of exposure. The T2 mean values in the $4^{\text {th }}$ week of exposure are significantly higher than other treatments including the control. The T4 mean values of the $6^{\text {th }}$ week are significantly higher than other treatments. The T1 and T3 mean values of the $8^{\text {th }}$ and $10^{\text {th }}$ weeks of exposure, respectively are significantly higher than other treatments. The highest GSH level in the liver exposed to this toxicant was $38.85 \pm 0.07 \mu \mathrm{g} / \mathrm{ml}$ obtained in T4 at the end of the $6^{\text {th }}$ week of exposure. (Table 1). In another development, the T2 mean values in the kidney of the samples in both $2^{\text {nd }}$ and $4^{\text {th }}$ weeks of exposure are significantly higher than other treatments including the control. Likewise, the T3 mean values in both $6^{\text {th }}$ and $10^{\text {th }}$ weeks of exposure, respectively are significantly higher than other treatments including the control. The control mean values in the $8^{\text {th }}$ week of control are significantly higher than other treatments. The highest GSH mean value produced in the kidney in this case, was $23.68 \pm 0.10 \mu \mathrm{g} / \mathrm{ml}$ obtained in $\mathrm{T} 3$ at the end of the $10^{\text {th }}$ week of exposure. (Table 2 ). On the other 
hand, the GSH production level in the gill indicated that T1 and T4 mean values in the $2^{\text {nd }}$ and $4^{\text {th }}$ weeks of exposure, respectively are significantly higher than other treatments including the control. The T2 mean values in both $6^{\text {th }}$ and $8^{\text {th }}$ weeks of exposure, respectively are significantly higher than other treatments including the control. The T3 mean values in the 10th week of exposure are significantly higher than other treatments including the control. The highest GSH value was $17.49 \pm 0.13 \mu \mathrm{g} / \mathrm{ml}$ obtained in $\mathrm{T} 1$ of the $2^{\text {nd }}$ week of exposure. (Table 3 ).

Table 2 GSH production levels in the Kidney of $C$. gariepinus exposed to sub-lethal concentrations of $\mathrm{CdCl}_{2}$ for a period of 12 weeks.

\begin{tabular}{|l|l|l|l|l|l|l|}
\hline $\begin{array}{l}\text { Treatment } \\
\text { group }\end{array}$ & \multicolumn{1}{|c|}{$\mathbf{1}^{\text {st }}$} & \multicolumn{1}{|c|}{$\mathbf{2}^{\text {nd }}$} & \multicolumn{1}{|c|}{$\mathbf{3}^{\text {rd }}$} & $\mathbf{4}^{\text {th }}$ & $\mathbf{5}^{\text {th }}$ & $\mathbf{6}^{\text {th }}$ \\
\hline CR & $9.88 \pm 0.07^{\mathrm{g}}$ & $11.70 \pm 0.13^{\mathrm{h}}$ & $13.80 \pm 0.03^{\mathrm{j}}$ & $16.13 \pm 0.13^{\mathrm{j}}$ & $18.80 \pm 0.10 \mathrm{~g}$ & $12.55 \pm 0.10^{\mathrm{d}}$ \\
\hline T1 & $8.00 \pm 0.16^{\mathrm{e}}$ & $7.46 \pm 0.25^{\mathrm{e}}$ & $9.71 \pm 0.10^{\mathrm{f}}$ & $11.35 \pm 0.13^{\mathrm{g}}$ & $9.14 \pm 0.03^{\mathrm{a}}$ & $7.15 \pm 0.07^{\mathrm{b}}$ \\
\hline T2 & $13.51 \pm 0.07^{\mathrm{k}}$ & $20.50 \pm 0.10^{\mathrm{l}}$ & $9.03 \pm 0.10^{\mathrm{e}}$ & $2.72 \pm 0.13^{\mathrm{a}}$ & $0.00 \pm 0.00$ & $0.00 \pm 0.00$ \\
\hline T3 & $7.54 \pm 0.10^{\mathrm{d}}$ & $5.50 \pm 0.10^{\mathrm{c}}$ & $17.09 \pm 0.03^{\mathrm{k}}$ & $11.58 \pm 0.07^{\mathrm{g}}$ & $23.68 \pm 0.10$ & $0.00 \pm 0.00$ \\
\hline T4 & $5.28 \pm 0.10^{\mathrm{b}}$ & $16.07 \pm 0.10^{\mathrm{k}}$ & $8.40 \pm 0.13^{\mathrm{d}}$ & $5.73 \pm 0.10^{\mathrm{d}}$ & $0.00 \pm 0.00$ & $0.00 \pm 0.00$ \\
\hline
\end{tabular}

Mean values and standard errors with different alphabets along the column are significantly different from each other at $\mathrm{P} \leq 0.05$. Unit of GSH mean value is $\mu \mathrm{g} / \mathrm{ml}$.

Table 3 GSH production levels in the Gill of $C$. gariepinus exposed to sub-lethal concentrations of $\mathrm{CdCl}_{2}$ for a period of 12 weeks.

\begin{tabular}{|l|l|l|l|l|l|l|}
\hline $\begin{array}{l}\text { Treatment } \\
\text { group }\end{array}$ & $\mathbf{1}^{\text {st }}$ & $\mathbf{2}^{\text {nd }}$ & $\mathbf{3}^{\text {rd }}$ & $\mathbf{4}^{\text {th }}$ & $\mathbf{5}^{\text {th }}$ & $\mathbf{6}^{\text {th }}$ \\
\hline CR & $12.55 \pm 0.16^{\mathrm{j}}$ & $2.72 \pm 0.07^{\mathrm{a}}$ & $4.88 \pm 0.07^{\mathrm{a}}$ & $13.29 \pm 0.13^{\mathrm{i}}$ & $16.35 \pm 0.07^{\mathrm{d}}$ & $13.68 \pm 0.10^{\mathrm{e}}$ \\
\hline T1 & $17.49 \pm 0.13^{\mathrm{l}}$ & $3.63 \pm 0.13^{\mathrm{b}}$ & $6.58 \pm 0.07^{\mathrm{c}}$ & $5.62 \pm 0.16^{\mathrm{d}}$ & $13.34 \pm 0.56^{\mathrm{c}}$ & $8.23 \pm 0.03^{\mathrm{c}}$ \\
\hline T2 & $12.38 \pm 0.13^{\mathrm{ij}}$ & $10.67 \pm 0.07^{\mathrm{g}}$ & $11.58 \pm 0.07^{\mathrm{h}}$ & $29.71 \pm 0.03^{\mathrm{l}}$ & $0.00 \pm 0.00$ & $0.00 \pm 0.00$ \\
\hline T3 & $6.81 \pm 0.20^{\mathrm{c}}$ & $2.95 \pm 0.07^{\mathrm{a}}$ & $6.58 \pm 0.13^{\mathrm{c}}$ & $12.43 \pm 0.10^{\mathrm{h}}$ & $16.98 \pm 0.03^{\mathrm{e}}$ & $0.00 \pm 0.00$ \\
\hline T4 & $4.93 \pm 0.16^{\mathrm{a}}$ & $12.66 \pm 0.16^{\mathrm{i}}$ & $5.50 \pm 0.10^{\mathrm{b}}$ & $3.85 \pm 0.07^{\mathrm{b}}$ & $0.00 \pm 0.00$ & $0.00 \pm 0.00$ \\
\hline
\end{tabular}

Mean values and standard errors with different alphabets along the column are significantly different from each other at $\mathrm{P} \leq 0.05$. Unit of GSH mean value is $\mu \mathrm{g} / \mathrm{ml}$.

In the liver of the samples of $C$. gariepinus exposed to sub-lethal concentrations of $\mathrm{CdCl}_{2}$, and supplemented with vitamin A, the T3 mean values of GSH are significantly different from other treatments in the $2^{\text {nd }}$ week of exposure. The T1 mean values in the $4^{\text {th }}$ week of exposure are significantly higher than other treatments. This mean value $(93.97 \pm 0.07 \mu \mathrm{g} / \mathrm{ml})$ was also the highest GSH produced in the liver of the fish in this case. The T4 and T2 mean values of the $6^{\text {th }}$ and $8^{\text {th }}$ weeks are significantly higher than other treatments. (Table 4).

Table $4 \mathrm{GSH}$ production levels in the Liver of $C$. gariepinus exposed to sub-lethal concentrations of $\mathrm{CdCl}_{2}$ and supplemented with vitamin A for a period of 12 weeks.

\begin{tabular}{|l|l|l|l|l|l|l|}
\hline $\begin{array}{l}\text { Treatment } \\
\text { group }\end{array}$ & $\mathbf{1}^{\text {st }}$ & $\mathbf{2}^{\text {nd }}$ & $\mathbf{3}^{\text {rd }}$ & $\mathbf{4}^{\text {th }}$ & $\mathbf{5}^{\text {th }}$ & $\mathbf{6}^{\text {th }}$ \\
\hline CR & $19.76 \pm 0.13^{\mathrm{j}}$ & $7.26 \pm 0.13^{\mathrm{g}}$ & $13.51 \pm 0.07^{\mathrm{h}}$ & $19.03 \pm 0.10^{\mathrm{k}}$ & $9.42 \pm 0.07^{\mathrm{a}}$ & $57.83 \pm 0.13^{\mathrm{c}}$ \\
\hline $\mathrm{T} 1$ & $7.60 \pm 0.13^{\mathrm{d}}$ & $93.97 \pm 0.07^{\mathrm{l}}$ & $10.10 \pm 0.07^{\mathrm{d}}$ & $6.92 \pm 0.07^{\mathrm{d}}$ & $0.00 \pm 0.00$ & $0.00 \pm 0.00$ \\
\hline $\mathrm{T} 2$ & $5.33 \pm 0.13^{\mathrm{b}}$ & $5.16 \pm 0.10^{\mathrm{c}}$ & $0.00 \pm 0.00$ & $16.01 \pm 0.07^{\mathrm{i}}$ & $0.00 \pm 0.00$ & $0.00 \pm 0.00$ \\
\hline T3 & $20.79 \pm 0.07^{\mathrm{k}}$ & $3.23 \pm 0.10^{\mathrm{b}}$ & $8.40 \pm 0.13^{\mathrm{c}}$ & $8.85 \pm 0.07^{\mathrm{ef}}$ & $0.00 \pm 0.00$ & $0.00 \pm 0.00$ \\
\hline T4 & $9.54 \pm 0.07^{\mathrm{f}}$ & $6.64 \pm 0.16^{\mathrm{e}}$ & $11.98 \pm 0.16^{\mathrm{f}}$ & $3.00 \pm 0.03^{\mathrm{a}}$ & $0.00 \pm 0.00$ & $0.00 \pm 0.00$ \\
\hline
\end{tabular}


In another development, the T3, T1 and T4 mean values in the kidney of the samples in the $2^{\text {nd }}, 4^{\text {th }}$ and $6^{\text {th }}$ weeks of exposure are significantly higher than other treatments. Likewise, the T2 mean values in $8^{\text {th }}$ week of exposure are significantly higher than other treatments. The highest GSH mean value produced in the kidney in this case, was $33.12 \pm 0.03 \mu \mathrm{g} / \mathrm{ml}$ obtained in T2 at the end of the $8^{\text {th }}$ week of exposure. (Table 5). On the other hand, the GSH production level in the gill indicated that T1 and T3 mean values in the $2^{\text {nd }}$ and $4^{\text {th }}$ weeks of exposure, respectively are significantly higher than other treatments. The T4 and T2 mean values in both $6^{\text {th }}$ and $8^{\text {th }}$ weeks of exposure, respectively are significantly higher than other treatments. The highest GSH value was $67.72 \pm 0.13 \mu \mathrm{g} / \mathrm{ml}$ obtained in T4 of the $6^{\text {th }}$ week of exposure. (Table 6).

Table $5 \mathrm{GSH}$ production levels in the Kidney of C. gariepinus exposed to sub-lethal concentrations of $\mathrm{CdCl}_{2}$ and supplemented with vitamin A for a period of 12 weeks.

\begin{tabular}{|l|l|l|l|l|l|l|}
\hline $\begin{array}{l}\text { Treatment } \\
\text { group }\end{array}$ & $\mathbf{1}^{\text {st }}$ & $\mathbf{2}^{\text {nd }}$ & $\mathbf{3}^{\text {rd }}$ & $\mathbf{4}^{\text {th }}$ & $\mathbf{5}^{\text {th }}$ & $\mathbf{6}^{\text {th }}$ \\
\hline CR & $9.88 \pm 0.07^{\mathrm{f}}$ & $11.70 \pm 0.13^{\mathrm{k}}$ & $13.80 \pm 0.03^{\mathrm{g}}$ & $16.13 \pm 0.13^{\mathrm{i}}$ & $18.80 \pm 0.10^{\mathrm{d}}$ & $12.55 \pm 0.10^{\mathrm{a}}$ \\
\hline T1 & $9.87 \pm 0.13^{\mathrm{f}}$ & $9.88 \pm 0.07^{\mathrm{j}}$ & $12.04 \pm 0.07^{\mathrm{f}}$ & $8.74 \pm 0.07^{\mathrm{e}}$ & $0.00 \pm 0.00$ & $0.00 \pm 0.00$ \\
\hline T2 & $10.50 \pm 0.10^{\mathrm{g}}$ & $5.73 \pm 0.10^{\mathrm{d}}$ & $6.47 \pm 0.07^{\mathrm{b}}$ & $33.12 \pm 0.03^{\mathrm{l}}$ & $0.00 \pm 0.00$ & $0.00 \pm 0.00$ \\
\hline T3 & $10.56 \pm 0.13^{\mathrm{g}}$ & $6.40 \pm 0.10^{\mathrm{e}}$ & $6.01 \pm 0.52^{\mathrm{b}}$ & $9.08 \pm 0.13^{\mathrm{fg}}$ & $0.00 \pm 0.00$ & $0.00 \pm 0.00$ \\
\hline T4 & $6.30 \pm 0.10^{\mathrm{c}}$ & $8.57 \pm 0.10^{\mathrm{i}}$ & $18.29 \pm 0.07^{\mathrm{i}}$ & $17.38 \pm 0.07^{\mathrm{j}}$ & $0.00 \pm 0.00$ & $0.00 \pm 0.00$ \\
\hline
\end{tabular}

Mean values and standard errors with different alphabets along the column are significantly different from each other at $\mathrm{P} \leq 0.05$. Unit of GSH mean value is $\mu \mathrm{g} / \mathrm{ml}$.

Table $6 \mathrm{GSH}$ production levels in the Gill of $C$. gariepinus exposed to sub-lethal concentrations of $\mathrm{CdCl}_{2}$ and supplemented with vitamin A for a period of 12 weeks.

\begin{tabular}{|l|l|l|l|l|l|l|}
\hline $\begin{array}{l}\text { Treatment } \\
\text { group }\end{array}$ & $\mathbf{1}^{\text {st }}$ & $\mathbf{2}^{\text {nd }}$ & $\mathbf{3}^{\text {rd }}$ & $\mathbf{4}^{\text {th }}$ & $\mathbf{5}^{\text {th }}$ & $\mathbf{6}^{\text {th }}$ \\
\hline CR & $12.55 \pm 0.16^{\mathrm{i}}$ & $2.72 \pm 0.10^{\mathrm{a}}$ & $4.88 \pm 0.07^{\mathrm{a}}$ & $13.29 \pm 0.13^{\mathrm{h}}$ & $16.35 \pm 0.07^{\mathrm{b}}$ & $13.68 \pm 0.10^{\mathrm{b}}$ \\
\hline T1 & $20.10 \pm 0.13^{\mathrm{j}}$ & $5.16 \pm 0.10^{\mathrm{c}}$ & $6.01 \pm 0.07^{\mathrm{b}}$ & $3.80 \pm 0.10^{\mathrm{b}}$ & $16.81 \pm 0.07^{\mathrm{c}}$ & $0.00 \pm 0.00$ \\
\hline T2 & $8.17 \pm 0.13^{\mathrm{e}}$ & $8.34 \pm 0.16^{\mathrm{hi}}$ & $29.59 \pm 0.03$ & $34.71 \pm 0.10^{\mathrm{m}}$ & $0.00 \pm 0.00$ & $0.00 \pm 0.00$ \\
\hline T3 & $4.48 \pm 0.16^{\mathrm{a}}$ & $15.73 \pm 0.10$ & $10.62 \pm 0.16^{\mathrm{e}}$ & $5.96 \pm 0.03^{\mathrm{c}}$ & $0.00 \pm 0.00$ & $0.00 \pm 0.00$ \\
\hline T4 & $11.07 \pm 0.16^{\mathrm{h}}$ & $8.23 \pm 0.10^{\mathrm{h}}$ & $67.72 \pm 0.13^{\mathrm{j}}$ & $9.14 \pm 0.10^{\mathrm{g}}$ & $0.00 \pm 0.00$ & $0.00 \pm 0.00$ \\
\hline
\end{tabular}

Mean values and standard errors with different alphabets along the column are significantly different from each other at $\mathrm{P} \leq 0.05$. Unit of GSH mean value is $\mu \mathrm{g} / \mathrm{ml}$.

Table $7 \mathrm{GSH}$ production levels in the Liver of $C$. gariepinus exposed to sub-lethal concentrations of $\mathrm{CdCl}_{2}$ and supplemented with vitamin $\mathrm{C}$ for a period of 12 weeks.

\begin{tabular}{|l|l|l|l|l|l|l|}
\hline Treatment group & $\mathbf{1}^{\text {st }}$ & $\mathbf{2}^{\text {nd }}$ & $\mathbf{3}^{\text {rd }}$ & $\mathbf{4}^{\text {th }}$ & $\mathbf{5}^{\text {th }}$ & $\mathbf{6}^{\text {th }}$ \\
\hline CR & $19.76 \pm 0.13^{\mathrm{i}}$ & $7.26 \pm 0.13^{\mathrm{f}}$ & $13.51 \pm 0.07^{\mathrm{j}}$ & $19.03 \pm 0.10^{\mathrm{l}}$ & $9.42 \pm 0.07^{\mathrm{a}}$ & $57.83 \pm 0.13^{\mathrm{e}}$ \\
\hline T1 & $14.03 \pm 0.10^{\mathrm{g}}$ & $12.72 \pm 0.13^{\mathrm{k}}$ & $15.22 \pm 0.07^{\mathrm{l}}$ & $5.56 \pm 0.07^{\mathrm{c}}$ & $9.71 \pm 0.10^{\mathrm{b}}$ & $10.73 \pm 0.03^{\mathrm{c}}$ \\
\hline T2 & $11.30 \pm 0.10^{\mathrm{e}}$ & $11.07 \pm 0.10^{\mathrm{i}}$ & $15.50 \pm 0.03^{\mathrm{m}}$ & $14.71 \pm 0.10^{\mathrm{j}}$ & $11.35 \pm 0.07^{\mathrm{c}}$ & $8.23 \pm 0.10^{\mathrm{b}}$ \\
\hline T3 & $6.98 \pm 0.10^{\mathrm{b}}$ & $10.33 \pm 0.07^{\mathrm{h}}$ & $21.07 \pm 0.03^{\mathrm{n}}$ & $0.00 \pm 0.00$ & $11.41 \pm 0.10^{\mathrm{c}}$ & $0.00 \pm 0.00$ \\
\hline T4 & $9.82 \pm 0.10^{\mathrm{d}}$ & $8.51 \pm 0.07^{\mathrm{g}}$ & $7.15 \pm 0.07^{\mathrm{c}}$ & $13.85 \pm 0.13^{\mathrm{h}}$ & $0.00 \pm 0.00$ & $0.00 \pm 0.00$ \\
\hline
\end{tabular}

Mean values and standard errors with different alphabets along the column are significantly different from each other at $\mathrm{P} \leq 0.05$.

Unit of GSH mean value is $\mu \mathrm{g} / \mathrm{ml}$.

In the liver of the samples of $C$. gariepinus exposed to sub-lethal concentrations of $\mathrm{CdCl}_{2}$, and supplemented with vitamin $\mathrm{C}$, the T1 mean values of GSH are significantly different from other treatments in both $2^{\text {nd }}$ and $4^{\text {th }}$ weeks of exposure, respectively. The T3 and T2 mean values in the $6^{\text {th }}$ and $8^{\text {th }}$ weeks of exposure are significantly higher than other 
treatments. Likewise, the T3 and T1 mean values in the $10^{\text {th }}$ and $12^{\text {th }}$ weeks of exposure are significantly higher than other treatments. The highest mean value was $21.07 \pm 0.03 \mu \mathrm{g} / \mathrm{ml}$ obtained in T3 at the end of the $6^{\text {th }}$ week of exposure. (Table 7).

In the kidneys of the samples exposed to CdVC treatments the T1 mean values in the $2^{\text {nd }}$ and $10^{\text {th }}$ weeks of exposure are significantly higher than other treatments, respectively. The T4 mean values in the $6^{\text {th }}$ and $8^{\text {th }}$ weeks of exposure are also significantly higher than other treatments. The T3 mean value $(50.05 \pm 0.03 \mu \mathrm{g} / \mathrm{ml})$ obtained in the $4^{\text {th }}$ week of exposure was the highest GSH value in the kidney of the fish. (Table 8). Likewise, the T3 mean values in $6^{\text {th }}$ and $8^{\text {th }}$ weeks of exposure are significantly higher than other treatments in the gills of the samples. The highest production was obtained in $\mathrm{T} 1$ at the $10^{\text {th }}$ week of exposure with $39.76 \pm 0.07 \mu \mathrm{g} / \mathrm{ml}$. (Table 9).

Table $8 \mathrm{GSH}$ production levels in the Kidney of C. gariepinus exposed to sub-lethal concentrations of $\mathrm{CdCl}_{2}$ and supplemented with vitamin $\mathrm{C}$ for a period of 12 weeks.

\begin{tabular}{|l|l|l|l|l|l|l|}
\hline $\begin{array}{l}\text { Treatment } \\
\text { group }\end{array}$ & $\mathbf{1}^{\text {st }}$ & $\mathbf{2}^{\text {nd }}$ & $\mathbf{3}^{\text {rd }}$ & $\mathbf{4}^{\text {th }}$ & $\mathbf{5}^{\text {th }}$ & $\mathbf{6}^{\text {th }}$ \\
\hline CR & $9.88 \pm 0.10^{\mathrm{d}}$ & $11.70 \pm 0.13^{\mathrm{j}}$ & $13.80 \pm 0.03^{\mathrm{k}}$ & $16.13 \pm 0.13^{\mathrm{k}}$ & $18.80 \pm 0.10^{\mathrm{h}}$ & $12.55 \pm 0.10^{\mathrm{d}}$ \\
\hline T1 & $12.09 \pm 0.16^{\mathrm{f}}$ & $8.74 \pm 0.07^{\mathrm{i}}$ & $8.57 \pm 0.03^{\mathrm{e}}$ & $11.01 \pm 0.07^{\mathrm{d}}$ & $19.76 \pm 0.13^{\mathrm{i}}$ & $8.23 \pm 0.03^{\mathrm{b}}$ \\
\hline T2 & $7.49 \pm 0.20^{\mathrm{c}}$ & $5.90 \pm 0.07^{\mathrm{c}}$ & $0.00 \pm 0.00$ & $4.99 \pm 0.07^{\mathrm{b}}$ & $0.00 \pm 0.00$ & $8.34 \pm 0.03^{\mathrm{b}}$ \\
\hline T3 & $5.84 \pm 0.16^{\mathrm{a}}$ & $50.05 \pm 0.03^{\mathrm{m}}$ & $10.28 \pm 0.10^{\mathrm{g}}$ & $12.15 \pm 0.07^{\mathrm{e}}$ & $13.46 \pm 0.10^{\mathrm{e}}$ & $0.00 \pm 0.00$ \\
\hline T4 & $7.38 \pm 0.07^{\mathrm{c}}$ & $1.47 \pm 0.13^{\mathrm{a}}$ & $10.56 \pm 0.07^{\mathrm{h}}$ & $14.08 \pm 0.07^{\mathrm{i}}$ & $0.00 \pm 0.00$ & $0.00 \pm 0.00$ \\
\hline
\end{tabular}

Mean values and standard errors with different alphabets along the column are significantly different from each other at $\mathrm{P} \leq 0.05$. Unit of GSH mean value is $\mu \mathrm{g} / \mathrm{ml}$.

Table $9 \mathrm{GSH}$ production levels in the Gill of $C$. gariepinus exposed to sub-lethal concentrations of $\mathrm{CdCl}_{2}$ and supplemented with vitamin $\mathrm{C}$ for a period of 12 weeks.

\begin{tabular}{|l|l|l|l|l|l|l|}
\hline $\begin{array}{l}\text { Treatment } \\
\text { group }\end{array}$ & $\mathbf{1}^{\text {st }}$ & $\mathbf{2}^{\text {nd }}$ & $\mathbf{3}^{\text {rd }}$ & $\mathbf{4}^{\text {th }}$ & $\mathbf{5}^{\text {th }}$ & $\mathbf{6}^{\text {th }}$ \\
\hline CR & $12.55 \pm 0.16^{\mathrm{f}}$ & $2.72 \pm 0.07^{\mathrm{ab}}$ & $4.88 \pm 0.07^{\mathrm{a}}$ & $13.29 \pm 0.13^{\mathrm{g}}$ & $16.35 \pm 0.07^{\mathrm{f}}$ & $13.68 \pm 0.10^{\mathrm{e}}$ \\
\hline T1 & $17.32 \pm 0.10^{\mathrm{h}}$ & $3.97 \pm 0.07^{\mathrm{b}}$ & $7.38 \pm 0.07^{\mathrm{d}}$ & $0.00 \pm 0.00$ & $39.76 \pm 0.07^{\mathrm{j}}$ & $6.75 \pm 0.03^{\mathrm{a}}$ \\
\hline T2 & $17.55 \pm 0.10^{\mathrm{h}}$ & $16.24 \pm 0.07^{\mathrm{l}}$ & $6.70 \pm 0.07^{\mathrm{b}}$ & $12.49 \pm 0.07^{\mathrm{f}}$ & $18.06 \pm 0.07^{\mathrm{g}}$ & $12.60 \pm 0.07^{\mathrm{d}}$ \\
\hline T3 & $9.88 \pm 0.07^{\mathrm{d}}$ & $6.07 \pm 0.16^{\mathrm{d}}$ & $11.53 \pm 0.10^{\mathrm{i}}$ & $22.83 \pm 0.13^{\mathrm{m}}$ & $12.04 \pm 0.20^{\mathrm{d}}$ & $0.00 \pm 0.00$ \\
\hline T4 & $19.88 \pm 0.07^{\mathrm{i}}$ & $7.04 \pm 2.10^{\mathrm{e}}$ & $8.91 \pm 0.10^{\mathrm{f}}$ & $4.25 \pm 0.03^{\mathrm{a}}$ & $0.00 \pm 0.00$ & $0.00 \pm 0.00$ \\
\hline
\end{tabular}

Mean values and standard errors with different alphabets along the column are significantly different from each other at $\mathrm{P} \leq 0.05$. Unit of GSH mean value is $\mu \mathrm{g} / \mathrm{ml}$.

Table $10 \mathrm{GSH}$ production levels in the Liver of $C$. gariepinus exposed to sub-lethal concentrations of $\mathrm{CdCl}_{2}$ and supplemented with vitamin $\mathrm{E}$ for a period of 12 weeks

\begin{tabular}{|l|l|l|l|l|l|l|}
\hline $\begin{array}{l}\text { Treatment } \\
\text { group }\end{array}$ & $\mathbf{1}^{\text {st }}$ & $\mathbf{2}^{\text {nd }}$ & $\mathbf{3}^{\text {rd }}$ & $\mathbf{4}^{\text {th }}$ & $\mathbf{5}^{\text {th }}$ & $\mathbf{6}^{\text {th }}$ \\
\hline CR & $19.76 \pm 0.13^{\mathrm{k}}$ & $7.26 \pm 0.11^{\mathrm{d}}$ & $13.51 \pm 0.07^{\mathrm{cd}}$ & $19.03 \pm 0.10^{\mathrm{i}}$ & $9.42 \pm 0.07^{\mathrm{a}}$ & $57.83 \pm 0.13^{\mathrm{h}}$ \\
\hline T1 & $8.80 \pm 0.10^{\mathrm{e}}$ & $6.07 \pm 0.49^{\mathrm{c}}$ & $13.63 \pm 0.07^{\mathrm{cd}}$ & $10.67 \pm 0.07^{\mathrm{f}}$ & $15.05 \pm 0.10^{\mathrm{c}}$ & $10.39 \pm 0.10^{\mathrm{c}}$ \\
\hline T2 & $11.24 \pm 0.07^{\mathrm{g}}$ & $7.26 \pm 0.20^{\mathrm{d}}$ & $14.99 \pm 0.20^{\mathrm{d}}$ & $8.00 \pm 0.10^{\mathrm{c}}$ & $11.47 \pm 0.10^{\mathrm{b}}$ & $14.71 \pm 0.10^{\mathrm{f}}$ \\
\hline T3 & $7.60 \pm 0.13^{\mathrm{c}}$ & $3.80 \pm 0.23^{\mathrm{b}}$ & $9.48 \pm 0.10^{\mathrm{b}}$ & $15.22 \pm 0.13^{\mathrm{h}}$ & $0.00 \pm 0.00$ & $0.00 \pm 0.00$ \\
\hline T4 & $5.84 \pm 0.16^{\mathrm{b}}$ & $15.22 \pm 0.13^{\mathrm{i}}$ & $8.12 \pm 0.36^{\mathrm{b}}$ & $10.28 \pm 0.03^{\mathrm{e}}$ & $0.00 \pm 0.00$ & $0.00 \pm 0.00$ \\
\hline
\end{tabular}

Mean values and standard errors with different alphabets along the column are significantly different from each other at $\mathrm{P} \leq 0.05$. Unit of GSH mean value is $\mu \mathrm{g} / \mathrm{ml}$. 
In the liver of the samples of $C$. gariepinus exposed to sub-lethal concentrations of $\mathrm{CdCl}_{2}$, and supplemented with vitamin E, the T2, T4 and T2 mean values of GSH are significantly different from other treatments in the $2^{\text {nd }}, 4^{\text {th }}$ and $6^{\text {th }}$ weeks of exposure, respectively. Similarly, the T3, T1 and T2 mean values in the $8^{\text {th }}, 10^{\text {th }}$ and $12^{\text {th }}$ weeks of exposure are significantly higher than other treatments. The highest GSH mean value in this regard was $15.22 \pm 0.13 \mu \mathrm{g} / \mathrm{ml} \mathrm{obtained}$ in both T4 and T3 at the end of the $4^{\text {th }}$ and $8^{\text {th }}$ weeks of exposure, respectively. (Table 10).

Table $11 \mathrm{GSH}$ production levels in the Kidney of $C$. gariepinus exposed to sub-lethal concentrations of $\mathrm{CdCl}_{2}$ and supplemented with vitamin $\mathrm{E}$ for a period of 12 weeks

\begin{tabular}{|l|l|l|l|l|l|l|}
\hline $\begin{array}{l}\text { Treatment } \\
\text { group }\end{array}$ & $\mathbf{1}^{\text {st }}$ & $\mathbf{2}^{\text {nd }}$ & $\mathbf{3}^{\text {rd }}$ & $\mathbf{4}^{\text {th }}$ & $\mathbf{5}^{\text {th }}$ & $\mathbf{6}^{\text {th }}$ \\
\hline CR & $9.88 \pm 0.07^{\mathrm{f}}$ & $11.70 \pm 0.13^{\mathrm{g}}$ & $13.80 \pm 0.03^{\mathrm{d}}$ & $16.13 \pm 0.13$ & $18.80 \pm 0.10^{\mathrm{e}}$ & $12.55 \pm 0.10^{\mathrm{d}}$ \\
\hline T1 & $11.24 \pm 0.13^{\mathrm{g}}$ & $8.91 \pm 0.03^{\mathrm{f}}$ & $9.31 \pm 0.07^{\mathrm{b}}$ & $7.15 \pm 0.07^{\mathrm{b}}$ & $26.35 \pm 0.07^{\mathrm{f}}$ & $4.65 \pm 0.07^{\mathrm{b}}$ \\
\hline T2 & $7.83 \pm 0.13^{\mathrm{c}}$ & $8.23 \pm 0.10^{\mathrm{e}}$ & $0.00 \pm 0.00$ & $10.28 \pm 0.10^{\mathrm{e}}$ & $0.00 \pm 0.00$ & $0.00 \pm 0.00$ \\
\hline T3 & $6.24 \pm 0.07^{\mathrm{b}}$ & $32.89 \pm 0.10$ & $9.25 \pm 0.03^{\mathrm{b}}$ & $13.34 \pm 0.10^{\mathrm{g}}$ & $0.00 \pm 0.00$ & $0.00 \pm 0.00$ \\
\hline T4 & $4.99 \pm 0.07^{\mathrm{a}}$ & $3.29 \pm 0.07^{\mathrm{b}}$ & $14.03 \pm 0.03^{\mathrm{d}}$ & $5.67 \pm 0.07^{\mathrm{a}}$ & $0.00 \pm 0.00$ & $0.00 \pm 0.00$ \\
\hline
\end{tabular}

Mean values and standard errors with different alphabets along the column are significantly different from each other at $\mathrm{P} \leq 0.05$. Unit of GSH mean value is $\mu \mathrm{g} / \mathrm{ml}$.

In another development, the T1 and T3 mean values in the kidney of the samples in the $2^{\text {nd }}$ and $4^{\text {th }}$ weeks of exposure, respectively are significantly higher than other treatments. Likewise, the T4 and T2 mean values in the $6^{\text {th }}$ and $8^{\text {th }}$ weeks of exposure are significantly higher than other treatments. The highest GSH mean value produced in the kidney in this case, was $32.89 \pm 0.10 \mu \mathrm{g} / \mathrm{ml}$ obtained in T3 at the end of the $4^{\text {th }}$ week of exposure. (Table 11).

Table 12 GSH production levels in the Gill of $C$. gariepinus exposed to sub-lethal concentrations of $\mathrm{CdCl}_{2}$ and supplemented with vitamin $\mathrm{E}$ for a period of 12 weeks

\begin{tabular}{|l|l|l|l|l|l|l|}
\hline $\begin{array}{l}\text { Treatment } \\
\text { group }\end{array}$ & $\mathbf{1}^{\text {st }}$ & $\mathbf{2}^{\text {nd }}$ & $\mathbf{3}^{\text {rd }}$ & $\mathbf{4}^{\text {th }}$ & $\mathbf{5}^{\text {th }}$ & $\mathbf{6}^{\text {th }}$ \\
\hline CR & $12.55 \pm 0.16^{\mathrm{h}}$ & $2.72 \pm 0.07^{\mathrm{a}}$ & $4.88 \pm 0.07^{\mathrm{a}}$ & $13.29 \pm 0.13^{\mathrm{g}}$ & $16.35 \pm 0.07^{\mathrm{d}}$ & $13.68 \pm 0.10^{\mathrm{e}}$ \\
\hline T1 & $8.34 \pm 0.16^{\mathrm{d}}$ & $12.66 \pm 0.23^{\mathrm{h}}$ & $11.70 \pm 0.07^{\mathrm{c}}$ & $5.39 \pm 0.10^{\mathrm{a}}$ & $16.24 \pm 0.07^{\mathrm{d}}$ & $18.40 \pm 0.13^{\mathrm{g}}$ \\
\hline T2 & $8.68 \pm 0.23^{\mathrm{de}}$ & $7.38 \pm 0.07^{\mathrm{d}}$ & $4.71 \pm 0.10^{\mathrm{a}}$ & $15.22 \pm 0.13^{\mathrm{h}}$ & $27.60 \pm 0.13^{\mathrm{g}}$ & $3.91 \pm 0.10^{\mathrm{a}}$ \\
\hline T3 & $17.66 \pm 0.10^{\mathrm{j}}$ & $2.43 \pm 0.10^{\mathrm{a}}$ & $11.70 \pm 0.07^{\mathrm{c}}$ & $9.08 \pm 0.13^{\mathrm{d}}$ & $0.00 \pm 0.00$ & $0.00 \pm 0.00$ \\
\hline T4 & $13.57 \pm 0.30^{\mathrm{i}}$ & $7.26 \pm 0.07^{\mathrm{d}}$ & $19.65 \pm 2.36^{\mathrm{e}}$ & $19.48 \pm 0.10^{\mathrm{j}}$ & $0.00 \pm 0.00$ & $0.00 \pm 0.00$ \\
\hline
\end{tabular}

Mean values and standard errors with different alphabets along the column are significantly different from each other at $\mathrm{P} \leq 0.05$. Unit of GSH mean value is $\mu \mathrm{g} / \mathrm{ml}$.

On the other hand, the GSH production level in the gill indicated that T1 and T3 mean values in the $2^{\text {nd }}$ and $4^{\text {th }}$ weeks of exposure, respectively are significantly lower than other treatments. The T4 mean values in both $6^{\text {th }}$ and $8^{\text {th }}$ weeks of exposure, respectively are significantly higher than other treatments. T2 and $\mathrm{T} 1$ in the $10^{\text {th }}$ and $12^{\text {th }}$ weeks of exposure, respectively are significantly higher than other treatments. The highest GSH value was $27.60 \pm 0.13 \mu \mathrm{g} / \mathrm{ml} \mathrm{obtained}$ in T2 of the $10^{\text {th }}$ week of exposure. (Table 12).

\section{Discussion}

GSH production levels in C. gariepinus exposed to sub-lethal concentrations of $\mathrm{CdCl}_{2}$ toxicant and the respective supplemented treatments with Vitamins A, C and E.

In the liver of the samples of $C$. gariepinus exposed to sub-lethal concentrations of $\mathrm{CdCl}_{2}$, there were general low levels of production. This is probably because cadmium is deleterious, and as such led to utilization of the antioxidant in combating the effects posed. This is also probably why the control mean values of GSH are significantly higher than other treatments in the $2^{\text {nd }}$ week of exposure. As the duration increased more GSH productions were probably elicited to up-regulate the body's defense systems in order to counteract the effects of the toxicant especially in higher 
concentration treatments. Hence, the T2 mean values in the $4^{\text {th }}$ week of exposure are significantly higher than other treatments including the control, the T4 mean values of the $6^{\text {th }}$ week are significantly higher than other treatments. Likewise, the T1 and T3 mean values of the $8^{\text {th }}$ and $10^{\text {th }}$ weeks of exposure, respectively are significantly higher than other treatments and the highest GSH level in the liver exposed to this toxicant was $38.85 \pm 0.07 \mu \mathrm{g} / \mathrm{ml}$ obtained in $\mathrm{T} 4 \mathrm{at}$ the end of the $6^{\text {th }}$ week of exposure; since the defensive homeostatic mechanism of cells and tissues combat metal intoxication either by sequestering the metal in a harmless way or by enhanced excretion of the toxic metal [8].

In another development, the T2 mean values in the kidney of the samples in both $2^{\text {nd }}$ and $4^{\text {th }}$ weeks of exposure are significantly higher than other treatments including the control. The production levels of the antioxidant were triggered early in T2 most likely to upstage the effects of the toxicant before the fish can actually adapt to the prevailing conditions in its environment. Subsequently, it was the turn of a higher concentration as the duration increases. This is probably why the T3 mean values in both $6^{\text {th }}$ and $10^{\text {th }}$ weeks of exposure, respectively is significantly higher than other treatments including the control; and the highest GSH mean value produced in the kidney in this case, was $23.68 \pm 0.10 \mu \mathrm{g} / \mathrm{ml}$ obtained also in T3 at the end of the $10^{\text {th }}$ week of exposure. Similar report was given by Saglam et al. [26] that there were increased activity of glutathione in the liver and kidney of fresh water fish, Oreochromis niloticus exposed to cadmium and copper toxicants. Also, Fatima et al. [15] reported that there were reduced activities of superoxide dismutase (SOD), catalase (CAT) and GSH in both species, and significant distortions in histology of liver, kidney and brain of affected fishes. On the other hand, the GSH production level in the gill indicated that T1 and T4 mean values in the $2^{\text {nd }}$ and $4^{\text {th }}$ weeks of exposure, respectively are significantly higher than other treatments including the control. The gill being the portal of entry, the elicitation took place in the lowest concentration treatment. Subsequently, the T2 mean values in both $6^{\text {th }}$ and $8^{\text {th }}$ weeks of exposure, respectively are significantly higher than other treatments including the control; and the T3 mean values in the 10th week of exposure are significantly higher than other treatments including the control. The highest GSH value was $17.49 \pm 0.13 \mu \mathrm{g} / \mathrm{ml}$ obtained in T1 of the $2^{\text {nd }}$ week of exposure. This is probably because the antioxidant produced early in the exposure were not put to too much utilization as it the case in higher concentrations.

In the liver of the samples of $C$. gariepinus exposed to sub-lethal concentrations of $\mathrm{CdCl}_{2}$, and supplemented with vitamin A, the T3 mean values of GSH are significantly different from other treatments in the $2^{\text {nd }}$ week of exposure. At this stage there was probably an urgent need to up-regulate the defense system to counter the xenobiotic in the environment of the fish. The impact was subsequently felt in T1 mean values in the $4^{\text {th }}$ week of exposure where they are significantly higher than other treatments; and at this low concentration there were probably less utilization in combating the effects posed by the toxicant due to the presence of the vitamin in the water matrix. This is also probably why this mean value $(93.97 \pm 0.07 \mu \mathrm{g} / \mathrm{ml})$ was the highest GSH produced in the liver of the fish in this case. The T4 and T2 mean values of the $6^{\text {th }}$ and $8^{\text {th }}$ weeks are significantly higher than other treatments probably because the responses are both duration and concentration dependent. Jamakala and Rani [18] stated that when Oreochromis mossambicus was exposed to Cd toxicity there was elevation of bioaccumulation of $\mathrm{Cd}$ in muscle tissues but upon supplementation with $\mathrm{Zn}$ or Ca accumulation of the toxicant was progressively reduced in all the test tissues.

In another development, the T3, T1 and T4 mean values in the kidneys of the samples in the $2^{\text {nd }}, 4^{\text {th }}$ and $6^{\text {th }}$ weeks of exposure are significantly higher than other treatments. Likewise, the T2 mean values in $8^{\text {th }}$ week of exposure are significantly higher than other treatments. The production level in the kidney was elicited early in the T3 and subsequently in other treatments as the duration increases. The elicitation of the antioxidant in T2 was probably less utilized in this later stage of the exposure, hence, this GSH mean value $(33.12 \pm 0.03 \mu \mathrm{g} / \mathrm{ml})$ produced in the kidney in this case, and obtained in T2 at the end of the $8^{\text {th }}$ week of exposure was also the highest. Furthermore, the GSH production level in the gill indicated that T1 and T3 mean values in the $2^{\text {nd }}$ and $4^{\text {th }}$ weeks of exposure, respectively are significantly higher than other treatments. The detection started early with the lowest concentration probably due to less utilization and the presence of the vitamin, hence its availability. However, as the concentration and duration increased the T4 and T2 mean values in both $6^{\text {th }}$ and $8^{\text {th }}$ weeks of exposure, respectively are significantly higher than other treatments; and the highest GSH value $(67.72 \pm 0.13 \mu \mathrm{g} / \mathrm{ml})$ was also obtained in T4 of the $6^{\text {th }}$ week of exposure.

In the liver of the samples of $C$. gariepinus exposed to sub-lethal concentrations of $\mathrm{CdCl}_{2}$, and supplemented with vitamin $\mathrm{C}$, the T1 mean values of GSH are significantly different from other treatments in both $2^{\text {nd }}$ and $4^{\text {th }}$ weeks of exposure, respectively. The availability of the antioxidant for detection in this lowest concentration may be due to less utilization and the succor provided by the vitamin. Subsequently, the need for higher production of the antioxidant probably becomes more sacrosanct in dealing with the toxicant as the duration of exposure increases. This is probably why the $\mathrm{T} 3$ and $\mathrm{T} 2$ mean values in the $6^{\text {th }}$ and $8^{\text {th }}$ weeks of exposure are significantly higher than other treatments; and the highest mean value $(21.07 \pm 0.03 \mu \mathrm{g} / \mathrm{ml})$ was also obtained in $\mathrm{T} 2$ at the end of the $6^{\text {th }}$ week of exposure. Likewise, the T3 and $\mathrm{T} 1$ mean values in the $10^{\text {th }}$ and $12^{\text {th }}$ weeks of exposure are significantly higher than other treatments probably due to the need for up-regulation of the body's defense at later stages of the exposure especially in the lowest concentration 
of the toxicant. In another development, the kidney displayed varying production levels of the antioxidant and the T2 mean values in $8^{\text {th }}$ week of exposure are significantly higher than other treatments. The highest GSH mean value produced in the kidney in this case, was $(50.05 \pm 0.03 \mu \mathrm{g} / \mathrm{ml})$ obtained also in T3 at the end of the $4^{\text {th }}$ week of exposure. At this stage of exposure, the need for up-regulation of the body's immune system probably becomes more pertinent in dealing with the deleterious effects of the toxicant in the kidney. On the other hand, the GSH production levels in the gill indicated that T1 and T3 mean values in the $2^{\text {nd }}$ and $4^{\text {th }}$ weeks of exposure, respectively are significantly higher than other treatments. The gill which is the first point of entry to the toxicant probably elicited and detected the onslaught of the lowest concentration. This is probably due to the underutilization of the antioxidant and the presence of the vitamin in the environment of the fish. The T1 mean value $(39.76 \pm 0.07 \mu \mathrm{g} / \mathrm{ml})$ obtained in the $10^{\text {th }}$ week of exposure was the highest GSH value in the gill of the fish probably due to the up-regulation of the body's defence system.

In the liver of the samples of $C$. gariepinus exposed to sub-lethal concentrations of $\mathrm{CdCl}_{2}$, and supplemented with vitamin E, the T2, T4 and T3 mean values of GSH are significantly different from other treatments in the $2^{\text {nd }}, 4^{\text {th }}$ and $6^{\text {th }}$ weeks of exposure, respectively. In this case there were early elicitation of the antioxidant in the presence of the vitamin and subsequently increase in its production as the concentration and duration of exposure increases. Similarly, the T3, T1 and $\mathrm{T} 2$ mean values in the $8^{\text {th }}, 10^{\text {th }}$ and $12^{\text {th }}$ weeks of exposure are significantly higher than other treatments. This is probably because at later stages of the exposure there is the need for production of the antioxidant for sustenance and survival. The highest GSH mean value in this regard was $15.22 \pm 0.13 \mu \mathrm{g} / \mathrm{ml}$ obtained in both T4 and T3 at the end of the $4^{\text {th }}$ and $8^{\text {th }}$ weeks of exposure, respectively probably due to the need for up-regulation of the antioxidant production levels despite utilization. Yulin et al. [31] reported how cell viability was significantly reduced following Cd exposure, but the vitamin $C$ supplementation (though not vitamin $E$ ) attenuated the increase in cell viability, vitamin $C$ can increase the antioxidation response and MT and immune-related gene expression. In another development, the T1 and T3 mean values in the kidney of the samples in the $2^{\text {nd }}$ and $4^{\text {th }}$ weeks of exposure, respectively are significantly higher than other treatments; and the highest GSH mean value produced $(32.89 \pm 0.10 \mu \mathrm{g} / \mathrm{ml})$ was also obtained in T3 at the end of the $4^{\text {th }}$ week of exposure. In this case, the sensitivity of the kidney is probably brought to bear in the presence of the vitamin at early stages of the exposure. In line with this, Ezedom et al. [11] stated that the Cd-contaminated diet was found to be more toxic to the kidney while the arsenic was found to be more toxic to the liver and that alterations in enzymatic activities and levels of MDA and GSH were also recorded. Subsequently, the T4 and T2 mean values in the $6^{\text {th }}$ and $8^{\text {th }}$ weeks of exposure are significantly higher than other treatments. This again is probably because there must be upregulation of the defense system of the body at the later stages of the exposure. On the other hand, the GSH production level in the gill indicated that T1 and T3 mean values in the $2^{\text {nd }}$ and $4^{\text {th }}$ weeks of exposure, respectively are significantly higher than other treatments; and the T4 mean values in both $6^{\text {th }}$ and $8^{\text {th }}$ weeks of exposure, respectively are significantly higher than other treatments. The same reasons given above are probably also tenable such that increased production in the early stages had to be improved upon at later stages of the exposure in the higher concentrations. T2 and $\mathrm{T} 1$ in the $10^{\text {th }}$ and $12^{\text {th }}$ weeks of exposure, respectively are significantly higher than other treatments. The highest GSH value was $27.60 \pm 0.13 \mu \mathrm{g} / \mathrm{ml}$ obtained in T2 of the $10^{\text {th }}$ week of exposure. In these lower concentrations and later stages of the exposure the elicited production levels were probably sustained with lesser utilization, and also likely due to the presence of the vitamin in the environment of the fish samples. In the work of Adi et al. [2] Cd exposure led to decrease in SOD, CAT, GR, GPx activities and a concomitant increase in LPx and GST activities, and that Ca+Zn and vitamin E administration with Cd significantly reversed Cd-induced perturbation in oxidative stress marker enzymes. They also found that vitamin E exhibited more inhibitory activity against $\mathrm{Cd}$ than did Ca+Zn, and it protected against $\mathrm{Cd}$-induced nephrotoxicity. Furthermore, the vitamin $\mathrm{E}$ and $\mathrm{C}$ mixture modulated the oxidative stress induced by ZnONPs (zinc oxide nano-particles) [4].

\section{Conclusion}

The various treatment groups displayed different levels of production of the antioxidant. There were general low production level in the Cd only group with the control mean values significantly higher than other treatments and the highest production was recorded in the liver. The liver recorded the highest GSH value of $38.85 \pm 0.07 \mu \mathrm{g} / \mathrm{ml}$.

There were improved production level of the antioxidant in the CdVA group and the highest production was also recorded in the liver as $93.97 \pm 0.07 \mu \mathrm{g} / \mathrm{ml}$.

The CdVC group produced the highest GSH level in the kidneys of the fish with $50.05 \pm 0.03 \mu \mathrm{g} / \mathrm{ml}$; while the highest production of the antioxidant in the CdVE group was recorded in the kidney with $32.89 \pm 0.10 \mu \mathrm{g} / \mathrm{ml}$.

The elicitation and utilization of the antioxidant at one point or the other were adopted by the fish in dealing with the effects of the toxicant. Higher concentrations of the vitamins could facilitate the understanding of the effects of the vitamins in mitigating the effects of the toxicant. 


\section{Compliance with ethical standards}

\section{Acknowledgments}

The authors wish to appreciate the department of Water, Aquaculture and Fisheries Technology and their technical staff for allowing access to their facilities and the assistance provided by the staff during the exposure period. We also appreciate the services of STEP B of the University for facilitating the assay of the antioxidants.

\section{Disclosure of conflict of interest}

The authors declare that there is no conflict of interest.

\section{References}

[1] Adewolu MA, Adeniji CA, Adejobi AB. Feed utilization, growth and survival of Clarias gariepinus (Burchell, 1822) fingerlings cultured under different photoperiods. Aquaculture. 2008; 283: 64-67.

[2] Adi PJ, Matcha B. Calcium, zinc and vitamin E ameliorate cadmium-induced renal oxidative damage in albino wistar rats. Toxicology reports. 2016; 3: 591-597.

[3] Ahmed NF, Sadek KM, Soliman MK, Khalil RH, Khafaga AF, Ajarem JS, Maodaa SN, Allam AA. Moringa Oleifera Leaf Extract Repairs the Oxidative Misbalance following Sub-Chronic Exposure to Sodium Fluoride in Nile Tilapia Oreochromis niloticus. Animals. 2020; 10: 626.

[4] Alkaladi A. Vitamins E and C ameliorate the oxidative stress induced by zinc oxide nano-particles on liver and gills of Oreochromis niloticus. Saudi Journal of Biological Sciences. 2019; 26(2): 357-362.

[5] Athar T, Waris AA, Nisar M. A review on toxicity and environmental implications of heavy metals. Emergent Life Sciences Research. 2018; 4(2): 31-37.

[6] Ayyat MS, Ayyat AM, Naiel MA, Al-Sagheer AA. Reversal effects of some safe dietary supplements on lead contaminated diet induced impaired growth and associated parameters in Nile tilapia. Aquaculture. 2020; 515: 734580 .

[7] Ayoola SO, Idowu AA, Babalola OE, Ademoye MK. Heavy metals accumulation and Enzymatic Biomarker in Commercially Important Fish Species (Hemichromis fasciatus and Chrysichthys nigrodigitatus) at the Landing Site, Bariga, Lagos Lagoon. World Applied Sciences Journal. 2014; 29(2): 298-306.

[8] Das S, Tseng L, Chou C, Wang L, Souissi S, Hwang J. Effects of Cadmium Exposure on Antioxidant Enzymes and Histological Changes in the Mud Shrimp, Austinogebia edulis (Crustacea: Decapoda). Environmental Science Pollution Research and Interactions. 2019; 26(8): 7752-7762.

[9] Ellman GL. Tissue sulfhydryl groups. Archive Biochemistry and Biophysics. 1959; 82: 70-77.

[10] El-Shenawy NS, Al-Ghamdi OA. Phenthoate induced oxidative stress in fresh isolated mice hepatocytes. Alleviation by ascorbic acid. Toxicology, Environment and Health Science. 2014; 6(2): 67-80.

[11] Ezedom T, Asagba S, Tonukari NJ. Toxicological effects of te concurrent administration of Cd and As through the food chain on the liver and kidney of rats. The Journal of Basic and Applied Zoology. 2020; 81: 160.

[12] FAO. Food Security: concepts and measurement. Rome: Food and Agriculture Organization of the United Nations. In FAO (Ed.), Trade Reforms and Food Security. 2003; 25-34.

[13] FAO. Food and Agricultural Organization of the United Nations: World Review of Fisheries and Aquaculture. 2010.

[14] FAO. The state of the world fisheries and aquaculture. Fisheries and Aquaculture Department, Rome. 2012.

[15] Fatima M, Usmani N, Firdaus F, Zafeer MF, Ahmed S, Akhtar K. In vivo induction of antioxidant response and oxidative stress associated with genotoxicity and histopathological alteration in two commercial fish species due to heavy metals exposure in northern India (Kali) river. Comparative Biochemistry and Physiology, Part C: Toxicology and Pharmacology. 2015; 76: 17-30.

[16] Feng Y, Huang X, Duan Y, Fan W, Duan J, Wang K, Yang S. The Effects of Vitamin E and Metallothionein on the AntioxidantCapacities of Cadmium-Damaged Liver in Grass Carp, Ctenopharyngodon idellus. BioMed Research International. 2018; 1-8. 
[17] Hermenean A, Damache G, Albu P, Ardelean A, Ardelean G, Ardelean DP, Dinischiotu A. Histopatological alterations and oxidative stress in liver and kidney of Leuciscus cephalus following exposure to heavy metals in the Tur River, North Western Romania. Ecotoxicology and Environmental Safety. 2015; 119: $198-205$.

[18] Jamakala O, Rani AU. Zinc and calcium supplementation to combat cadmium induced bioaccumulation in fresh water teleost, Oreochromis mossambicus (Tilapia). International journal of Pharmacy and pharmaceutical Sciences. 2016; 8(11): 186-190.

[19] Karami A, Christianus A, Ishak Z, Courtenay SC, Sayed MA, Noor AM, Noor SH. Effect of triploidization on juvenile African catfish (Clarias gariepinus). Aquaculture International. 2010; 18: 851-858.

[20] Luschak VI. Environmentally induced oxidative stress in aquatic animals. Aquatic Toxicology. 2011; 1: 13-30.

[21] Marzouk M, Abdelkader EM, El-zayat M, Aboushady A. Assessing environmental impact indicators in road construction projects in developing countries. Sustainability. 2017; 9(5): 843.

[22] Mehana EE, Khafaga AF, Elblehi SS, AbdEl-Hack ME, Naiel MAE, Bin-Jumah M, SarahI Othman SI, Allam AA. Biomonitoring of Heavy Metal Pollution Using Acanthocephalans Parasite in Ecosystem: An Updated Overview. Animals. 2020; 10(811): 1-15.

[23] Organization for Economic Cooperation and Development. Maximum Acceptable Contaminants: guidance safety level. Fresh water fish (RPWS 1991). 2007; 12-28.

[24] Pratt TC, Cullen FT, Sellers CS, Thomas WL, Madensen TD, Daigle LE, Fearn NE, Gau J. The empirical status of social learning theory: a meta-analysis. Justice Quarterly. 2010; 27(6): 765-802.

[25] Rajagopalan R, Kode A, Penumatha SV, Kallikat NR, Venugopal PM. Comparative effects of curcumin and an analog of curcumin on alcohol and PUFA induced oxidative stress. Journal of Pharmacy and Pharmaceutical Science. 2004; 83: 2747-2752.

[26] Saglam D, Atli G, Dogan Z, Baysoy E, Gurler C, Eroglu A, Canli M. Response of the antioxidant system of freshwater fish (Oreochromis niloticus) exposed to metals $(\mathrm{Cd}, \mathrm{Cu})$ in different hardness. Turkish Journal of Aquatic Science. 2014; 14: 43-52.

[27] Sharma DK, Ansari BA. Effects of deltamethrin on CAT, LPO and GSH in tissues of zebra fish, Danio rerio. Research Journal of Environmental Toxicology. 2013; 7(1): 38-46.

[28] Sissein EA, Diepreye E, Tonkiri A, Asara AA. Nonenzymatic antioxidant levels as pollution biomarkers in liver of Clarias gariepinus harvested from Gbarantoru Swamp: a polluted site in Bayelsa State. Journal of Chemical, Biological and Physical Sciences. 2014; 4(3): 2325-2332.

[29] Tingman W, Jian Z, Xiaoshuan Z. Fish product quality evaluation based on temperature monitoring in cold chain. African Journal of Biotechnology. 2010; 9: 6146-6151.

[30] Yolanda M, Maria LI. Use of antioxidants for the treatment of cognitive and behavioural disorders in individuals with fragile X syndrome. WO2012080554. 2012.

[31] Yulin Y, Zhang P, Liu J, Wang N. Amelioration of Cd-induced oxidative stress, MT gene expression and immune damage by vitamin C in grass carp kidney cells. Biological Trace Elements Research. 2020; 194 